243

Received: September 15, 2017

Accepted: October 26, 2017
Macedonian Journal of Animal Science, Vol. 7, No. 1-2, pp. 107-115 (2017)

ISSN $1857-6907$

e-ISSN $1857-7709$

UDC: $636.7 .09:[616.612: 616.65-007.61$

Original scientific paper

\title{
DIAGNOSTIC IMAGING AND BIOLOGICAL CHARACTERISTICS OF SPERM AND SEMINAL PLASMA PROTEINS IN DOGS WITH BENIGN PROSTATIC HYPERPLASIA
}

\author{
Maria Ivanova $^{1 *}$, Desislava Gradinarska ${ }^{1}$, Miroslav Genov ${ }^{1,2}$, Diana Zasheva ${ }^{1}$, Boyko Georgiev ${ }^{1}$ \\ ${ }^{1}$ Bulgarian Academy of Sciences, Institute of Biology and Immunology of Reproduction \\ "Acad. Kiril Bratanov", Department of Reproductive Biotechnologies and Cryobiology of Gametes, \\ Blvd "Tsarigradsko shose" 73A, 1113 Sofia, Bulgaria \\ ${ }^{2}$ Central Veterinary Clinic - Sofia, Chavdar Mutafov Str. $25 B$ \\ "kichevamar@abv.bg
}

\begin{abstract}
The disease benign prostatic hyperplasia (BPH) occurs in men, dogs and less frequently in other species. BPH is a state of endocrine dysregulation related to age, which in dogs is most common in uncastrated males after 6 years of age. Information on the effect of BPH on semen quality and seminal plasma proteins (SPPs) is of great interest for the practice of artificial insemination and semen cryopreservation. The aim of this study was to evaluate the size and structure of the prostate by echographic and radiographic imaging; to assess semen quality by CASA and to compare by HPLC and SDS-PAGE analysis the SPPs profiles between healthy dogs (BPH-) and dogs with BPH (BPH+). The increase of the ejaculate volume $(4.96 \pm 2.28$ for $\mathrm{BPH}+$ and $3.59 \pm 2.0$ for $\mathrm{BPH}-, \mathrm{p}=0.03)$ and alkalization of sperm $(\mathrm{pH} 7.18 \pm 0.13$ for $\mathrm{BPH}+$ and $\mathrm{pH} 6.74 \pm 0.11$ for $\mathrm{BPH}-$ ) in $\mathrm{BPH}$ dogs were demonstrated. There were statistically significant differences in motility, progression and speed parameters of spermatozoa between the two groups. It has been shown that sperm head area in dogs with BPH is credibly smaller, $20.89 \pm 2.34 \mu \mathrm{m}^{2}$, whereas in comparison to healthy dogs this value is $29.11 \pm 6.21 \mu \mathrm{m}^{2}$. The results of HPLC assay showed that BPH is associated with changes in the amount and content of certain proteins from the seminal plasma (SP). Protein characterization gives information that proteins of the SP can serve as relevant markers for the evaluation of the biological potential of the sperm. As a conclusion of the research, it was found that BPH in dogs leads to statistically significant changes in motility and speed parameters of spermatozoa. We believe that these changes are the result of a modified protein profile of the SP, with a proven increased protein presence of high molecular weight (MW) around and above $200 \mathrm{kDa}$, and the presence of an increased amount of low MW proteins under $12.4 \mathrm{kDa}$.
\end{abstract}

Key words: dog; prostate; seminal plasma protein; spermatozoa

\section{БИОЛОШКИ КАРАКТЕРИСТИКИ НА СПЕРМАТОЗОИДИТЕ И СЕМЕНИТЕ ПЛАЗМЕНИ ПРОТЕИНИ КАЈ КУЧИЊАТА СО БЕНИГНА ХИПЕРПЛАЗИЈА НА ПРОСТАТАТА}

Бенигната хиперплазија на простатата (ВРН) се јавува кај мажи, кучиња и поретко кај други видови. ВРН е состојба на ендокрина дисрегулација поврзана со возраста, која кај кучињата е најчеста кај некастрирани мажјаци по 6 години старост. Информации за ефектот на ВРН врз квалитетот на спермата и семените плазмени протеини (SPPs) се од голем интерес за практиката на вештачко осеменување и криопрезервацијата на спермата. Целта на оваа студија беше да се процени големината и структурата на простатата со ехографски и радиографски слики; да се процени квалитетот на спермата со CASA и да се споредат со HPLC и SDSPAGEанализа профилите SPPs на здрави кучиња (BPH-) и кучиња со ВPH (BPH+). Зголемувањето на обемот на ејакулатот $(4,96 \pm 2,28$ за ВРН+ и 3,59 $\pm 2,0$ за ВРН-, $\mathrm{p}=0,03)$ и алкализацијата на спермата $(\mathrm{pH} 7,18 \pm 0,13$ за $\mathrm{BPH}+$ и рН 6,74 $\pm 0,11$ за ВРН-) кај кучиња со ВРН беа докажани. Статистички значајни разлики се утврдени во подвижноста, прогресијата и брзината на спермата помеѓу двете групи. Утврдено е дека областа на главата на спермата кај кучињата со ВРН е помала, $20,89 \pm 2,34 \mu \mathrm{m}^{2}$, додека кај здрави кучиња оваа вредност е $29,11 \pm$ $6,21 \mu \mathrm{m}^{2}$. Резултатите од HPLC покажа дека BPH е поврзана со промени во количеството и содржината на одредени протеини од семената плазма (SP). Протеиската карактеризацијата дава информации дека протеините на SP можат да послужат како релевантни маркери за евалуација на биолошкиот потенцијал на спермата. Како 


\begin{abstract}
заклучок од истражувањето беше утврдено дека ВРН кај кучињата доведува до статистички значајни промени во подвижноста и брзината на сперматозоидите. Ние веруваме дека овие промени се резултат на модифициран протеински профил на SP, со докажано зголемено присуство на протеин со висока молекуларна тежина (MW) од околу $200 \mathrm{kDa}$, како и присуство на зголемено количество протеини со мала MW (под 12,4 kDa).
\end{abstract}

Клучни зборови: куче; простата; семенски плазмапротеини; сперматозоиди

\section{INTRODUCTION}

Benign prostatic hyperplasia $(\mathrm{BPH})$ is the most common prostatic disorder and is found in most intact male dogs older than 6 years, as a result of androgenic stimulation or altered androgen-estrogen ratio. $\mathrm{BPH}$ is a condition in which the prostate gland is enlarged. This is not caused by bacterial or viral infection and it is not a form of cancer $[6,9,12,16]$. It is, rather, a normal aging process of the gland. As the dog continues to mature, the glandular tissue within the prostate undergoes hypertrophy. That is to say that there is an increase in both size and number of the cells within the glandular tissue. Till now, it is not known why some males are affected by $\mathrm{BPH}$, and others are not. It is known that the prostate gland depends on hormones from the testicles to regulate its size and function. As the balance of hormones in a dog's body changes with age, the prostate tends to enlarge as a result of excess production of androgens, especially testosterone and estrogen. $\mathrm{BPH}$ is a condition seen only in intact (unneutered) male dogs.

According to most sources, there is no established breed predisposition. Some authors supposed that Dihydrotestosterone is the biologically active hormone that contributes to the hypertrophy and hypersecretion of the epithelial cells of the prostate $[11,18]$.

Clinical signs may be absent, or tenesmus, persistent or intermittent haematuria, or haemorrhagic preputial discharge may occur. Once in a while, an enlarging prostate pushes forward rather than backward, pressing on the urethra. This can cause a dog to strain while urinating. Blood in the urine is one of the signs of BPH. Another symptom of BPH can be a thick, bloody discharge from the penis (originating in the urethra) $[2,7]$.

The diagnosis is suggested by physical and historical findings and by a nonpainful, symmetrically enlarged prostate. Radiology can confirm prostatomegaly. Ultrasonography should show diffuse, relatively symmetric involvement with multiple, diffuse, cystic structures. Cytological examination of massage or ejaculate specimens reveals haemorrhage with mild inflammation without evidence of sepsis or neoplasia. Definitive diagnosis is only possible by biopsy. Castration is the treatment of choice; prostatic involution is usually evident within a few weeks and is often complete in several months. All these - blood work, urinalysis, x-rays, ultrasound, urine culture and microscopic evaluation of fluid drawn from the prostate gland, can help confirm the diagnosis $[13,14,15,17]$. In diagnosing $\mathrm{BPH}$, it's important to rule out other causes of an enlarged prostate, including cysts, infection with inflammation (prostatitis), and cancer [8, 12].

Therapy by castration is the most effective treatment of BPH. Although treatment is only necessary if clinical signs are present, asymptomatic patients can still benefit from castration in regard to preventing the development of clinical signs. Hormonal therapy has long been recognized as a means to achieve reduction in the size of the enlarged prostate, but has many potential side effects. In addition, the hormones generally used in treatment affect the reproductive potential of the patient, limiting the usefulness of hormonal therapy in affected dogs that are kept intact for breeding purposes. Another therapy is hormonal by using of Estrogen, which depressed pituitary gonadotropin secretion, reducing testicular androgen secretion which ultimately results in prostatic atrophy, or Progestogens which can be used in the treatment of BPH, including megestrol acetate and medroxyprogesterone acetate $[19,20]$.

$\mathrm{BPH}$ is a non-cancerous enlargement of the gland. It is associated with the male sex hormone testosterone and is the most common disease of the prostate. The presence of BPH may change the biochemical composition of the prostate $[1,3,5,11]$. There are many unexplained matters regarding $\mathrm{BPH}$, but our main interest concerns the effects of the hyperplastic changes on semen quality, the role and composition of SPPs and in future to investigate the freezabilty of the spermatozoa in dogs with $\mathrm{BPH}$ $[4,6,10,18]$.

The aim of this study was to evaluate the size and structure of the prostate; to assess semen quality by CASA and to compare by HPLC analysis the SPPs profiles between healthy dogs and dogs with $\mathrm{BPH}$. 


\section{MATERIALS AND METHODS}

Intact mature male dogs older than 6 years $(n$ $=25$ ) of different breeds (Samoyed, Labrador, Bern Shepherd, French Bulldog, Caucasian Shepherd, English Bulldog, Bullmastiff) were assessed for $\mathrm{BPH}$ by echographic and radiographic imaging. Whole ejaculates from healthy dogs and from dogs with BPH were obtained manually and assessed via CASA. SPPs were separated and characterized by HPLC. Further characterization of SPPs was made by SDS-PAGE.

\section{Echographic and radiographic imaging}

All patients were subjected to prostate and testicular echography for evidence of ultrasound visible changes. Individuals with normal testicular ultrasound were used in the current study. The size of the prostate and the presence of secondary symptoms were radiologically evaluated. All regulations and requirements on animal welfare and safety were met when working with dogs and handling biological materials.

\section{Semen collection and evaluation}

Whole ejaculates from healthy dogs and dogs with $\mathrm{BPH}$ were obtained using digital manipulation. Volume, $\mathrm{pH}$ and sperm concentration were measured. Motility, progression, velocity and kinematic parameters of the spermatozoa were assessed by CASA System Sperm Class Analyzer ${ }^{\circledR}$ (Microptic $^{\circledR}$ ).

\section{Seminal plasma isolation}

SP was isolated from each ejaculate by double centrifugation. The semen was centrifuged $(1000 \times$ $\mathrm{g}, 5 \mathrm{~min}$ at room temperature) to obtain $\mathrm{SP}$ and then was further centrifuged $\left(10000 \times \mathrm{g}, 10 \mathrm{~min}\right.$ at $\left.4{ }^{\circ} \mathrm{C}\right)$. The isolated SP was filtered through $0.48 \mu \mathrm{m}$ filter membrane and stored at $-80^{\circ} \mathrm{C}$.

\section{High-performance liquid chromatography (HPLC)}

SPPs were separated and characterized by HPLC (Waters Company ${ }^{\circledR}$ ) at $\lambda=220 \mathrm{~nm}$ and $\lambda=$ $280 \mathrm{~nm}$, using a semi-preparative size exclusion chromatographic column TSK gel ${ }^{\circledR}$ G3000SW, 10 to $500 \mathrm{kDa}$ (Tosoh Bioscience ${ }^{\circledR}$ ). Sample volume of $150 \mu \mathrm{l}$ was applied at $30 \mathrm{~min}$ run time and $6 \mathrm{ml} / \mathrm{min}$ flow rate. Gel Filtration Markers Kit for Protein Molecular Weights 12,000 - 200,000 $\mathrm{Da}^{\mathrm{TM}}$ (SigmaAldrich $^{\circledR}$ ) was used for molecular weight (MW) determination.

\section{Spectrophotometric assay}

Each collected protein fraction was analyzed spectrophotometrically for protein concentration determination (Ultrospec 2000 UV / VIS Spectrophotometer, Pharmacia Biotech ${ }^{\circledR}$ ).

\section{Electrophoretic characterization of SPPs}

SPPs were further characterized by SDSPAGE - sodium dodecyl sulphate polyacrylamide gel electrophoresis. Total protein content in the SP was determined spectrophotometrically (Ultrospec 2000, Pharmacia Biotech ${ }^{\circledR}$ ). SP sample aliquots were diluted at 1:3 ratio with $4 \times$ Laemmli Sample buffer (Bio-Rad®), supplemented with $10 \% \beta$-mercaptoethanol, and heated for $2 \mathrm{~min}$ at $100^{\circ} \mathrm{C}$. SDSPAGE was performed at a constant voltage $(110 \mathrm{~V})$ in $12 \%$ gel $(25 \mu \mathrm{g}$ protein concentration per gel well) and $20 \%$ gel ( $3 \mu \mathrm{g}$ protein concentration per gel well). Silver staining was used for bands visualization. The MW of the protein bands was determined with Sigma Marker ${ }^{\mathrm{TM}}$ Wide Range 6,500 200,000 Da (Sigma-Aldrich ${ }^{\circledR}$ ).

\section{Statistical analysis}

Statistical analysis was made by Student's Ttest. Approximate MW of the protein bands was evaluated by MW standard curve in Excel (Figure 9).

\section{RESULTS}

On an echographic examination of a healthy prostate, the two lobes of the gland demonstrate symmetrical shape and size, normal echogenicity and homogeneous parenchymal structure (Figure 1).

In BPH both prostate lobes show symmetrical diffuse hyperechogenicity with or without the presence of one or several hypoechogenic cystic structures [4] (Figure 2).

The size of the healthy prostate should not be greater than $70 \%$ of the size of the pelvic floor as measured on lateral radiography. In $\mathrm{BPH}+$, the measurement demonstrates prostatomegaly - prostate size greater than $70 \%$ of the pelvic entrance $[2$, $12]$. Based on the results from the diagnostic imaging, the animals were distributed into two groups: healthy dogs (BPH-, $n=14$, mean age $5.48 \pm 2.92$ ), and dogs with evidence of $\mathrm{BPH}(\mathrm{BPH}+, n=19$, mean age $5.88 \pm 2.15$ ).

The analysis of the ejaculate volume, sperm concentration and $\mathrm{pH}$ showed a tendency to an increase in volume and decrease in sperm concentration in dogs with BPH (Figure 3). 


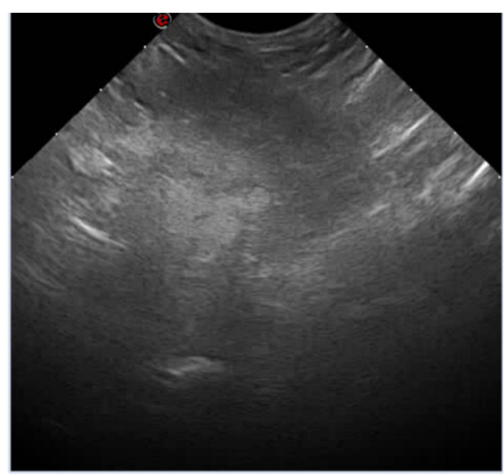

a)

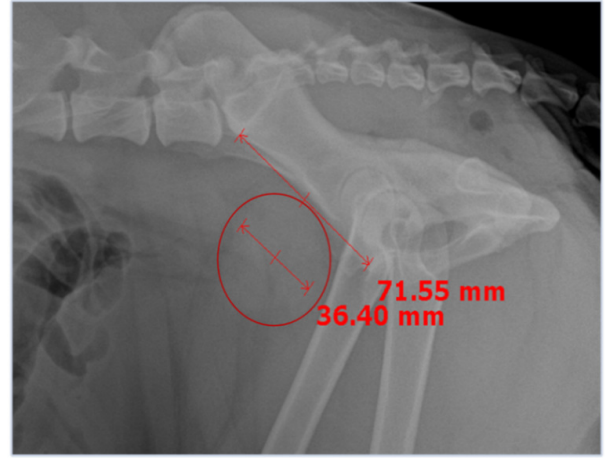

b)

Fig. 1. a) Healthy prostate ultrasound imaging. b) Healthy prostate lateral radiography and measurement

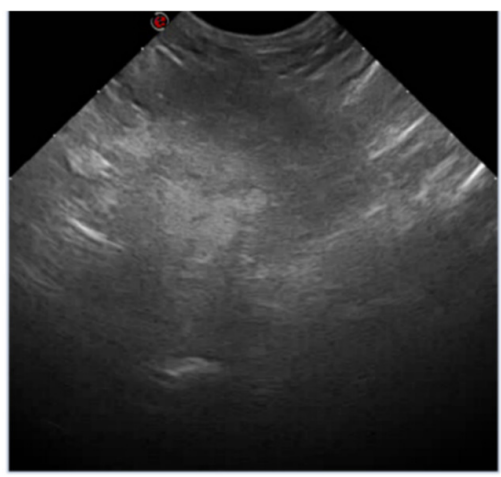

a)

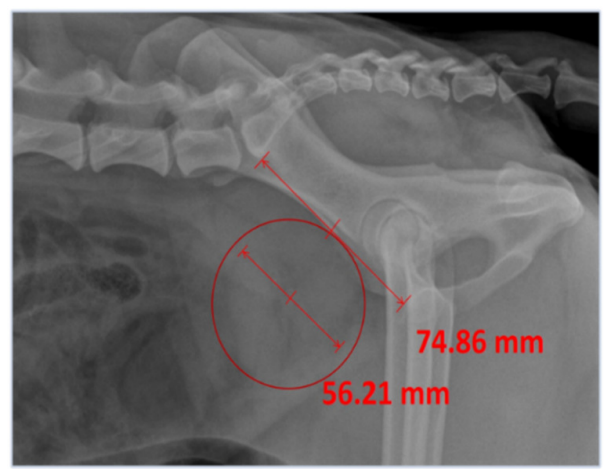

b)

Fig. 2. a) BPH ultrasound imaging. b) BPH lateral radiography and measurement

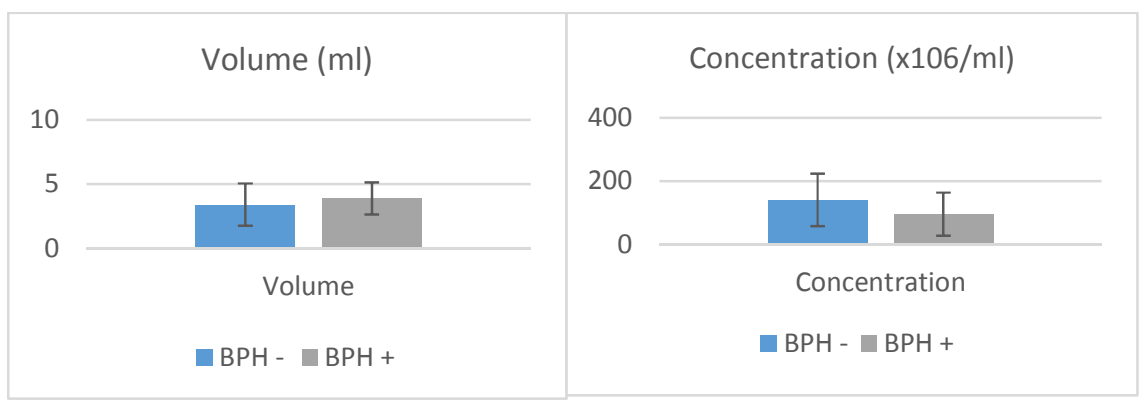

\section{$\mathrm{BPH}-(r=-0,80427)$}
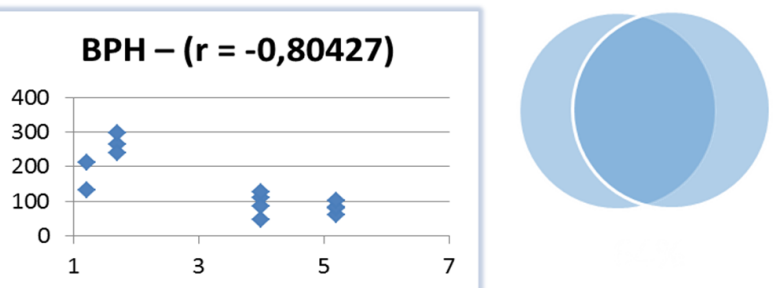

$64 \% \mathrm{pH} 6.79 \pm 0.14$
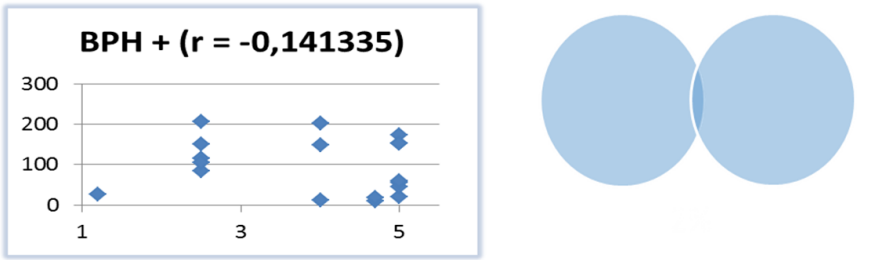

$2 \% \mathrm{pH} 6.79 \pm 0.14$

Fig. 3. Correlation between ejaculate volume and concentration of spermatozoa of the two groups. 
A strong negative correlation was established between the ejaculate volume and sperm concentration in healthy dogs, while in dogs with BPH that correlation was poorly expressed. Also, alkalization of the semen was registered in dogs with BPH.

The comparative CASA analysis on motility, progression and velocity of the spermatozoa showed significant differences between the two groups (Figure 4). The percentage of static spermatozoa was significantly higher in dogs with $\mathrm{BPH}$, compared to healthy dogs (BPH-.) Accordingly, the percentage of spermatozoa with progressive motility and spermatozoa with rapid and medium motility was lower in dogs with $\mathrm{BPH}$.

To specify these results we analyzed the kinematic parameters of the spermatozoa. Significant differences in VCL and VAP were found, showing the higher vigour of the spermatozoa of healthy dogs (Figure 5).

An interesting result, which is a novelty in the field of BPH studies in dogs, is the smaller area of the sperm head. Our data proves that sperm head area, as measured by the Motility and Concentration CASA module, in dogs with $\mathrm{BPH}$ is $20.89 \pm 2.34$, whereas this value is $29.11 \pm 6.21$ in $\mathrm{BPH}-(\mathrm{p}<$ 0.001) (Figure 6).

Especially interesting for us were the differences in the HPLC profiles of SPPs between the two groups. The SPPs profile of dogs with BPH demonstrated specific protein redistribution. The most significant changes are that high MW proteins, separated into a peak at the $7^{\text {th }}$ minute are significantly reduced in $\mathrm{BPH}+$. Also at $280 \mathrm{~nm}$ a considerably higher content of proteins, separated as a peak at $16^{\text {th }}$ minute can be observed (Figure 7).
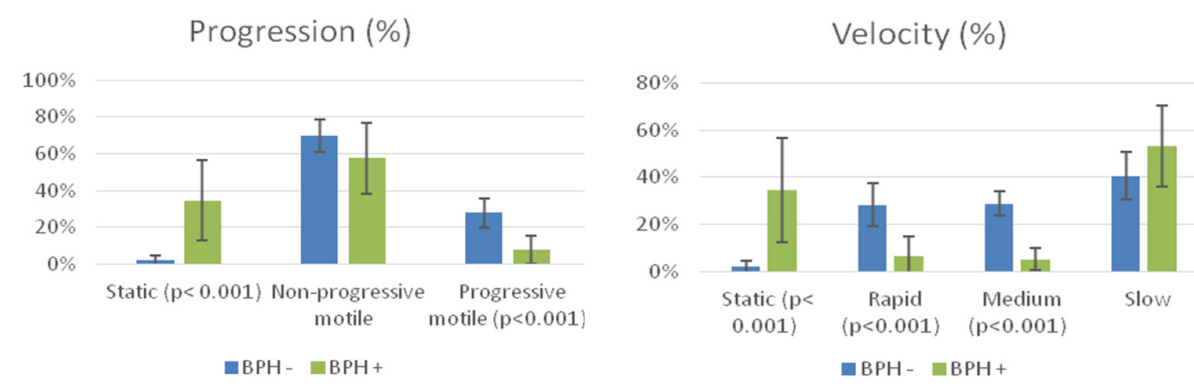

Fig. 4. Comparative CASA analysis on motility, progression and velocity of spermatozoa from the two group
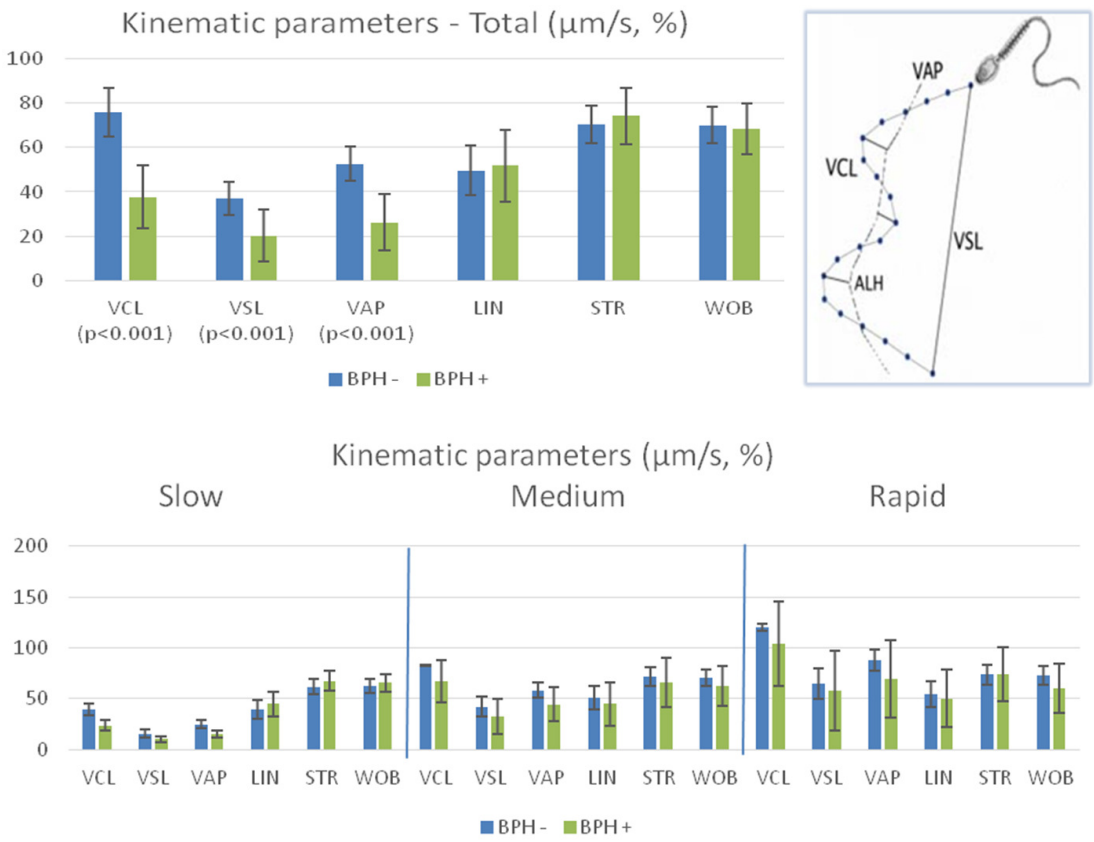

Fig. 5. Comparative CASA analysis on the kinematic parameters of the spermatozoa from the two groups 


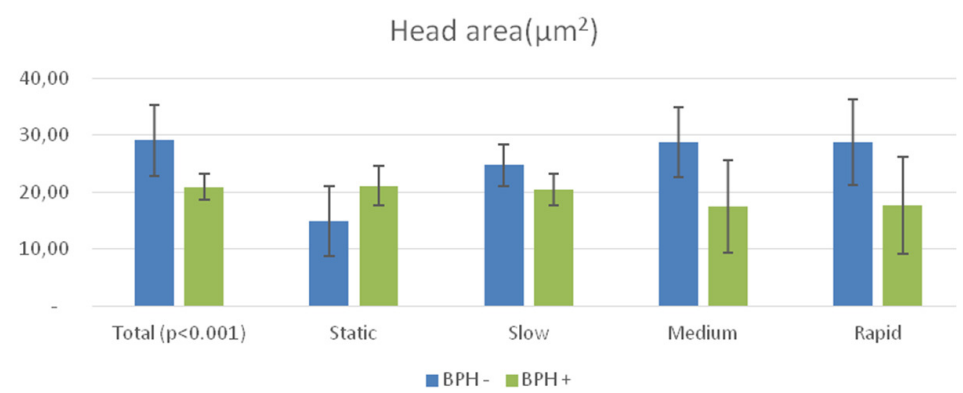

Fig. 6. Comparative CASA analysis of the sperm head area at $\mathrm{BPH}$ and $\mathrm{BPH}+(\mathrm{p}<0.001)$
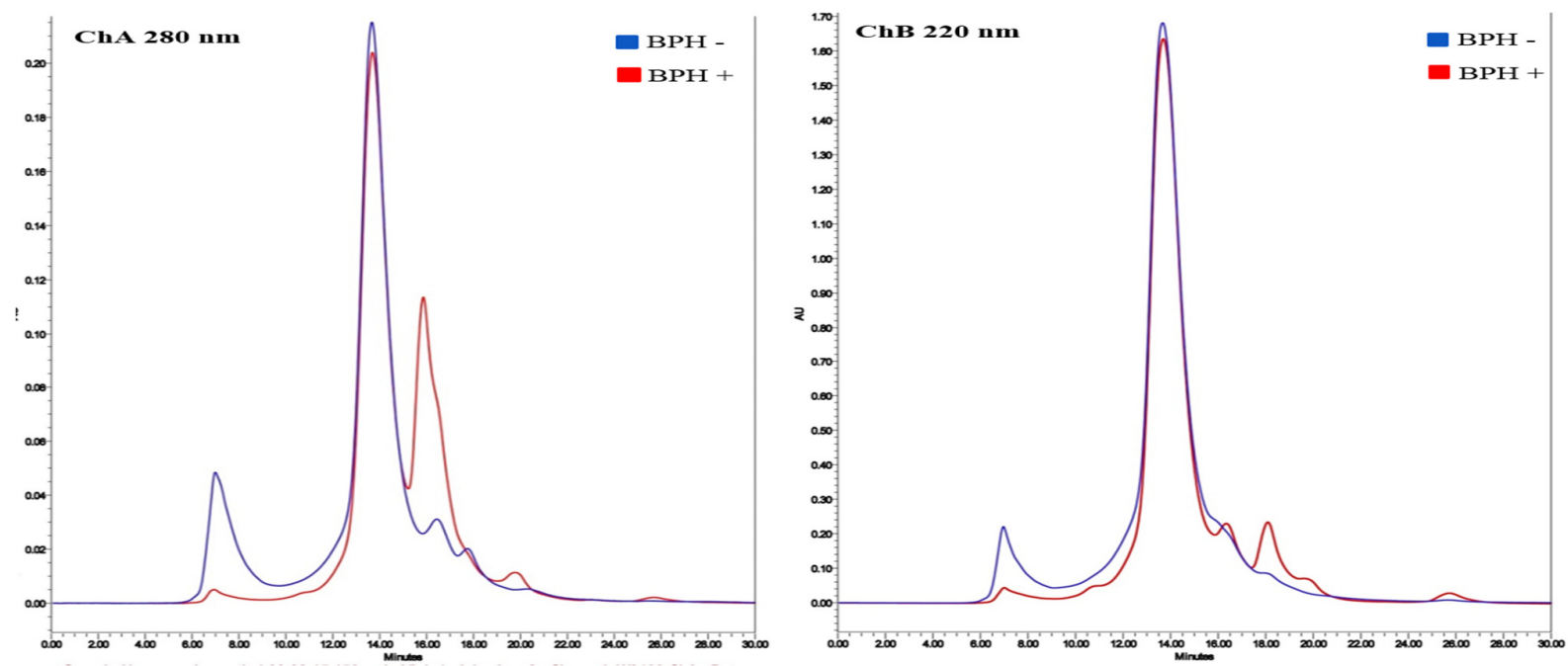

Fig. 7. Comparative HPLC analysis on the SPPs profiles between the two groups

At $220 \mathrm{~nm}$, a protein peak at 18th minute, formed by low MW proteins under $12 \mathrm{kDa}$ was registered, which is almost absent in samples from healthy dogs. At $\lambda=280 \mathrm{~nm}$, the results in dogs with $\mathrm{BPH}$ showed a decrease in the amount of high MW proteins with MW above $200 \mathrm{kDa}$, peaked at 7 minutes. Also, the 16-minute chromatographic peak corresponding to proteins with MW of less than 12 $\mathrm{kDa}$ with aromatic rings in their structure showed greater absorption in dogs with BPH. Specific peaks at 20th and 26th minute are observed, which are almost or completely absent in healthy dogs. The results of the HPLC assay at $\lambda=220 \mathrm{~nm}$ in dogs with BPH also showed a decrease in the absorbance of SPPs with MW over $200 \mathrm{kDa}$, differentiated in peak at 7 minutes. There is a well-defined peak at $18 \mathrm{mi}-$ nutes containing proteins with MW below $12 \mathrm{kDa}$, which is almost absent in samples from healthy dogs.

The spectrophotometric assay of SPPs fractions showed that $\mathrm{BPH}$ is associated with changes in the amount and content of some proteins from the SP (Table 1).
Table 1

Data on concentration of proteins contained in the separated protein fractions $(\mathrm{mg} / \mathrm{ml})$

\begin{tabular}{ccc}
\hline \hline Fraction & BPH- & BPH+ \\
\hline $\mathbf{1}$ & $0.057 \pm 0.008^{\mathrm{a}}$ & $0.015 \pm 0.004^{\mathrm{b}}$ \\
$\mathbf{2}$ & $0.544 \pm 0.135^{\mathrm{c}}$ & $0.429 \pm 0.059^{\mathrm{d}}$ \\
$\mathbf{3}$ & $0.062 \pm 0.006$ & $0.064 \pm 0.011$ \\
$\mathbf{4}$ & $0.025 \pm 0.004^{\mathrm{a}}$ & $0.067 \pm 0.012^{\mathrm{b}}$ \\
$\mathbf{5}$ & $0.002 \pm 0.001^{\mathrm{a}}$ & $0.025 \pm 0.005^{\mathrm{b}}$ \\
$\mathbf{6}$ & $0 \pm 0.001^{\mathrm{a}}$ & $0.005 \pm 0.002^{\mathrm{b}}$ \\
\hline \hline
\end{tabular}

\pm SEM, $(\mathrm{a}, \mathrm{b}-\mathrm{p}<0.001 ; \mathrm{c}, \mathrm{d}-\mathrm{p}<0.05)$

SDS-PAGE of the SP demonstrates differences in protein bands between the two studied groups. The differences were mainly found on the 
$12 \%$ gel, concerning the high MW proteins. No apparent differences were found on the $20 \%$ gel under these electrophoretic conditions.

The individual SP samples from BPH- showed a uniform picture of the SDS-PAGE profile. 7 clearly visible protein bands were identified on a $12 \%$ gel (Figures $8 \mathrm{~A}-5$ to 8 ) with the following approximate MW: 135.4, 125.7, 114.9, 108.2, 58.6, 48.9 and $33.2 \mathrm{kDa} .4$ protein bands were visualized on $20 \%$ gel (Figures $8 \mathrm{~B}-5$ to 8 ): $33.2,28.8,26.3$ and $23.3 \mathrm{kDa}$.

Samples from $\mathrm{BPH}+$ demonstrated 11 protein bands on the $12 \%$ gel (Figures $8 \mathrm{~A}-1$ to 4 ) with the following approximate MW: 135.4, 125.7, 114.9, 108.2, 103.4, 89.1, 76.7, 58.6, 48.9, 36.3 and 33.2 $\mathrm{kDa} .4$ protein bands were visualized on the $20 \%$ gel (Figures 8B - 1 to 4): 33.2, 28.8, 26.3 and $23.3 \mathrm{kDa}$.
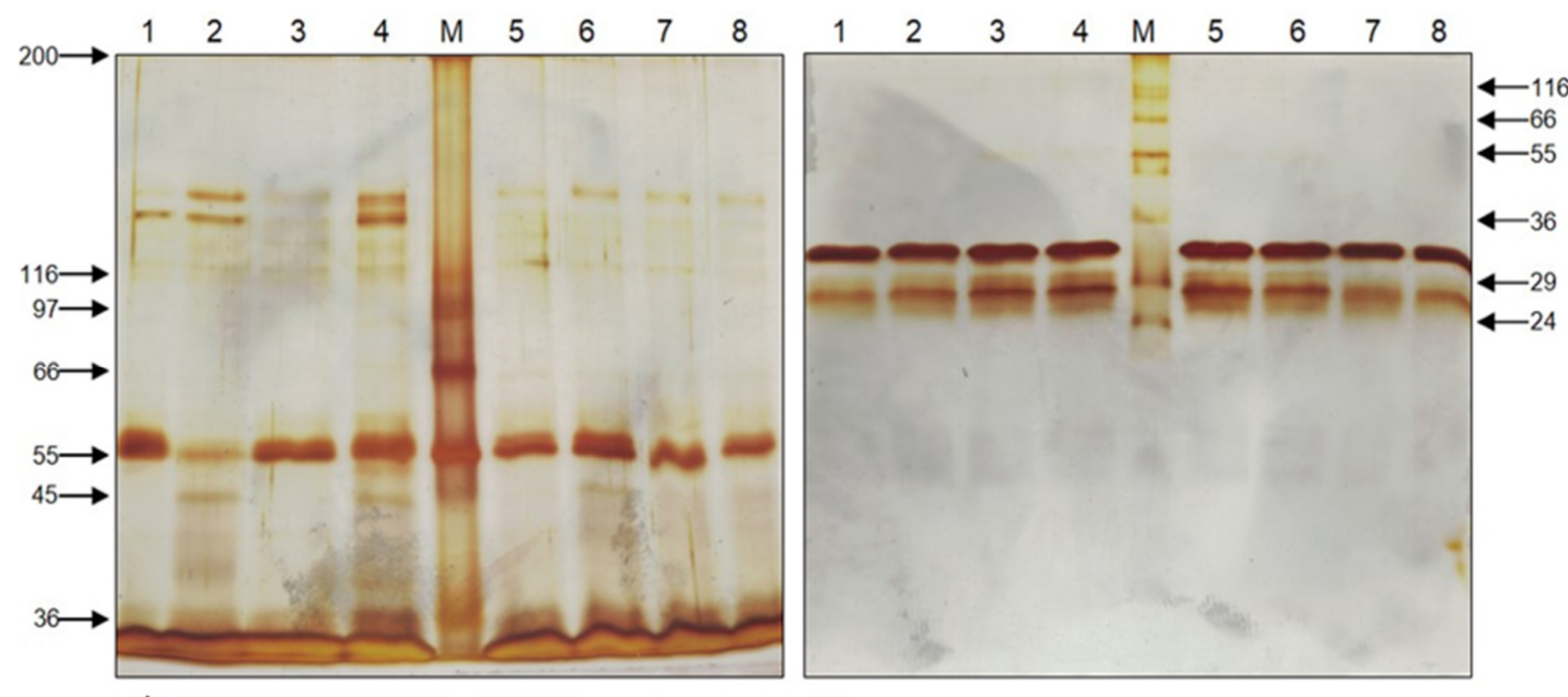

B

Fig. 8. SDS-PAGE of SP from healthy dogs and dogs with BPH on $12 \%$ gel (A) and $20 \%$ gel (B). $\mathrm{M}$ - marker; 1 to $4-\mathrm{BPH}+; 5$ to $8-\mathrm{BPH}$

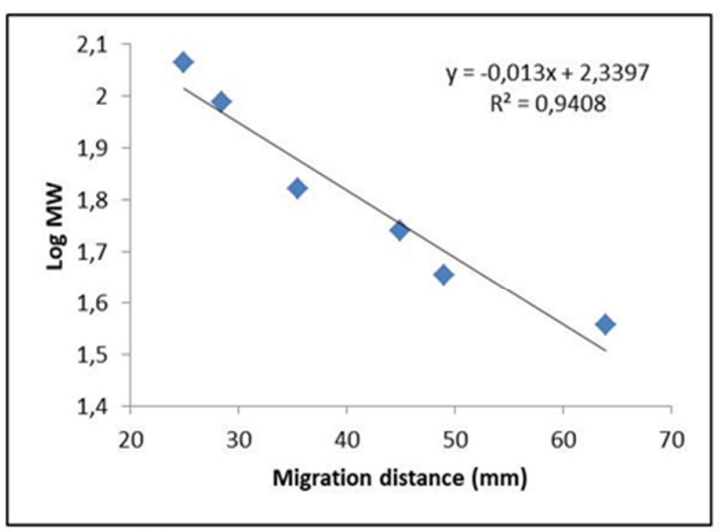

A

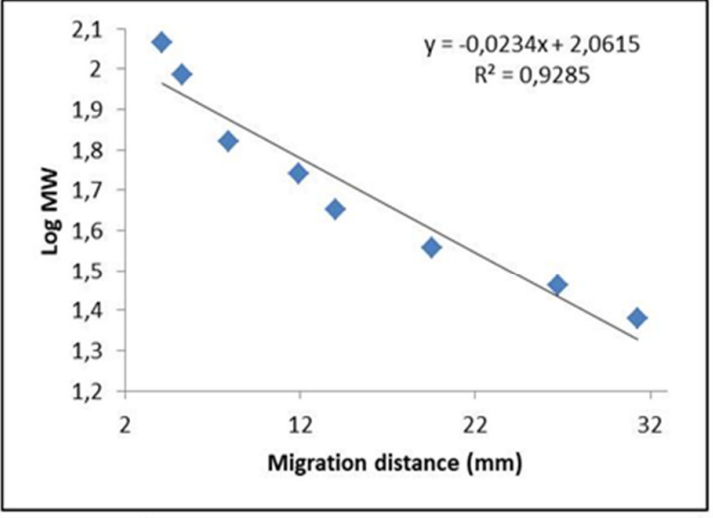

B

Fig. 9. Standard curve and equation for determination of the estimated MW of the proteins, separated by SDS-PAGE on $12 \%$ (A) and $20 \%$ (B) gel.

\section{DISCUSSION}

An important and innovative result is the smaller area $\left(\mu \mathrm{m}^{2}\right)$ of the sperm head in cases of $\mathrm{BPH}$, especially concerning the population of motile spermatozoa. Our hypothesis is that this difference is due to two main reasons. On the one hand, there are probably some disturbances in the spermatogenesis process due to the elevated testosterone levels in dogs with $\mathrm{BPH}[2,9]$. It has been shown that in $\mathrm{BPH}+$ one of the factors leading to the manifestation of the disease and the high level of testosterone [19, 
20]. On the other hand, we assume that some changes in the composition and $\mathrm{pH}$ of the SP may lead to changes in the structure and function of the sperm plasma membrane. BPH is definitely accompanied by specific changes in the biochemical composition of the SP that are caused by changes in prostate secretion $[3,7,15]$.

Our results obtained on the HPLC protein profile demonstrate that the protein content of the SP has credible differences between dogs with proven $\mathrm{BPH}$ and healthy dogs. Particularly high differences are found in proteins of the first fraction containing proteins with $\mathrm{MW}$ above $200 \mathrm{kDa}$ and those in the 4, 5 and 6 fractions, in which proteins with MW below 12.4 $\mathrm{kDa}$. In this regard, some authors have investigated the effect of prostatic fluid on motility, viability and acrosome integrity of canine spermatozoa $[5,6,18]$.

Differences were also found regarding the SDS-PAGE protein profile between the two studied groups. Variation in the density of high MW protein bands between individual $\mathrm{BPH}+$ samples, as well as between $\mathrm{BPH}+$ and $\mathrm{BPH}-$ was established, mainly with respect to the group of proteins with MW above $100 \mathrm{kDa}$. These data demonstrate an increased amount of high MW proteins with MW 135.4 and 125.7 $\mathrm{kDa}$ and low MW proteins with MW 48.9 and $36.3 \mathrm{kDa}$, which is a convincing result and are only observed in the case of BPH.

\section{CONCLUSION}

BPH leads to an increase in the volume and alkalinity of the ejaculate and lowering of the sperm concentration. Semen quality is affected and the spermatozoa have lower vigour and smaller head area. The SPPs profile is changed. Redistribution of proteins is registered with reduction in the concentration of high MW proteins and an increase in the concentration of certain groups of low MW proteins. Our results make it possible to assume that these proteins could be relevant markers for the sperm biological potential and will serve to develop and advance reproductive biotechnology in dogs.

Acknowledgment: This study was supported by grant DFNP-171/13.05.2016, "Program for career development of young scientists", Bulgarian Academy of Sciences.

\section{REFERENCES}

[1] Barrios B., Fernández-Juan M., Muiño-Blanco T., CebriánPérez J. A.: Immunocytochemical localization and biochemical characterization of two seminal plasma proteins that protect ram spermatozoa against cold shock, J Androl, 26 (4), 539-549 (2005).

[2] Berry S., Strandberg J. D., Saunders W. J., Coffey D. S.: Development of canine benign prostatic hyperplasia with age, The Prostate, 9 (4), 363-373 (1986).

[3] Branam J. E., Keen C. L., Ling G. V., Franti C. E.,: Selected physical and chemical characteristics of prostatic fluid collected by ejaculation from healthy dogs and from dogs with bacterial prostatitis, Am. J. Vet. Res., 45 (4), 825-829 (1984).

[4] Brandon C., Heusner G., Caudle A., Fayrer-Hosken R.: Two-dimensional polyacrylamide gel electrophoresis of equine seminal plasma proteins and their correlation with fertility, Theriogenology, 52 (5), 863-873 (1999).

[5] De Souza F. F., Barreto C. S., Lopes M. D.: Characteristics of seminal plasma proteins and their correlation with canine semen analysis, Theriogenology, 68 (1), 100-106 (2007).

[61 De Souza F. F., Martins M. I., Fernandes C. E., Ribolla P. E., Lopes M. D.: Heparin-binding proteins of canine seminal plasma, Theriogenology, 66 (6-7), 1606-1609 (2006).

[7] Feeney D. A, Johnston G. R., Klausner J. S., Perman V., Leininger J. R., Tomlinson M. J.: Reports of reproductive studies: Canine prostatic disease - comparison of radiographic appearance with morphologic and microbiologic findings: 30 cases (1981-1985), J. Am. Vet. Med. Assoc., 190 (8), 1018-1026 (1987).

[8] Hafez E. S. E.: Reproduction in Farm Animals, 6th edition, Lea \& Febiger, Philadelphia, 1993. ISBN 10: 0812115341 / ISBN 13: 9780812115345.

[9] Johnston S. D., Kamolpatana K., Root-Kustritz M. V., Johnston G. R.: Prostatic disorders in the dog, Animal Reproduction Science, 60-61, 405-415 (2000).

[10] Lilja H., Abrahamsson P. A.: Three predominant proteins secreted by the human prostate gland, Prostate, 12 (1), 29 38 (1988).

[11] Marconi M., Pilatz A., Wagenlehner F., Diemer T., Weidner W.: Impact of infection on the secretory capacity of the male accessory glands, Int. Braz. J. Urol., 35 (3), 299-308 (2009).

[12] Michelle Kutzler: Benign Prostatic Hyperplasia in Small Animals. Veterinary manual, Merck manual, 2017.

[13] Mogielnicka-Brzozowska M., Fraser L., Czarzasta J., Kordan W.: Isolation and characterization of zinc-binding proteins of canine seminal plasma, Polish Journal of Veterinary Sciences, 15 (3), 493-498 (2012).

[14] Muiño-Blanco T., Pérez-Pé R., Cebrián-Pérez J. A.: Seminal Plasma Proteins and Sperm Resistance to Stress, $R e$ production in Domestic Animals, 43, suppl. 4, 18-31 (2008). DOI: 10.1111/j.1439-0531.2008.01228.x.

[15] Neagu V., B. García, A. Rodríguez, C. Ferrusola, J. Bolaños et al.: Determination of glutation peroxidase and superoxide dismutase activities in canine seminal plasma and its relation with sperm quality and lipid peroxidation post thaw, Theriogenology, 75 (1), 10-16 (2011).

[16] Polisca A., Troisi A., Fontaine E., Menchetti L., Fontbonne A.: A retrospective study of canine prostatic diseases from 
2002 to 2009 at the Alfort Veterinary College in France, Theriogenology, 85 (5), 835-840 (2016).

[17] Rodríguez-Martínez H., Kvist U., Ernerudh J., Sanz L., Calvete J.: Seminal Plasma Proteins: What Role Do They Play? American Journal of Reproductive Immunology, $\mathbf{6 6}$ (s1), 11-22 (2011).

[18] Sirivaidyapong S, Ursem P., Colenbrander B.: Effect of prostatic fluid on motility, viability and acrosome integrity of chilled and frozen-thawed dog spermatozoa, $J$ Reprod Fertil, 57 (Suppl.), 383-6 (2001).

[19] Smith J.: Canine prostatic disease: A review of anatomy, pathology, diagnosis, and treatment, Theriogenology, $\mathbf{7 0}$, 375-383 (2008).

[20] Семков М., Иванова-Кичева М., Герзилов В.: Размножаване на домашните животни, Академично издателство на Аграрния университет, Пловдив, 2011. 
